\title{
ISLAMIC BANKING AND FINANCE AS AN ETHICAL ALTERNATIVE: A SYSTEMATIC LITERATURE REVIEW
}

\author{
JOHANNA PESENDORFER ${ }^{1}$, OTHMAR LEHNER ${ }^{2}$ \\ ${ }^{1}$ Oberbank AG \\ ${ }^{2}$ University of Oxford, Said Business School
}

\begin{abstract}
Despite huge global growth rates and a rapidly increasing importance of Islamic banking and finance, research in this area still needs to be classified as nascent. Recent economic events have led to an increasingly critical attitude towards the conventional banking and finance system, whereas Islamic banking is considered to be an ethical alternative not only in Muslim economies but also progressively in the "western" world. As their business models have their origins in religious and ethical ideals, Islamic banks struggle to observe the foundational Shariah principles while simultaneously meeting applicable guidelines such as Basel III and flexibly adapt to the ever changing customer demands. Due to the increasing importance of Islamic banking and finance, this article aims to analyse and summarise various aspects of current research and sets out to identify both, congruence and inconsistencies between the implied promise of an "ethical" alternative and the actual market.
\end{abstract}

Keywords: Islamic banking, Islamic finance, Shariah, Ethics, Sustainability

\section{Introduction}

Islamic banking, which syndicates the principles of Islamic law as its fundamentals has become increasingly significant for the global financial sector in recent decades. Within the global financial market, Islamic banks have established themselves as competitive alternatives with a variety of often differing products and services (Wajdi Dusuki, 2008). Forty years after the first modern Islamic bank had opened its door however it is still difficult to estimate the true size of this fast growing sector (Gheeraert, 2014). A study published by Ernst \& Young values the compound annual growth rate of worldwide Islamic banking assets from 2009 to 2013 at $17.6 \%$. An average growth rate of $19.7 \%$ per year is expected by 2018 (EY, 2014). Many Western banks e.g. HSBC, Citibank or the Bank of America have set up their own Islamic banking branches in different countries (F. Khan, 2010). Interestingly Islamic banks were hardly touched by the recent financial crises and see no recession in their volumes.

Islamic banks and even the branches set up in western countries differ from conventional banks in various ways. The most important difference can be seen in the prohibition of interest in Islam, which does not allow Islamic banks to let their customers have fixed interest payments for their deposits or to charge interest on loans (Chong \& Liu, 2009). Islamic law by contrast supports the theory that financial transactions should be grounded on a profit and loss sharing principle (Uppal \& Mangla, 2014). Furthermore it is important that an economic transaction involving a real asset backs every financial transaction (Beck, Demirgüç-Kunt, \& Merrouche, 2013). This approach triggers discussions regarding the risk profile and cost effectiveness of Islamic banks. The sharing of risk between the involved parties (borrower, investor and bank) leads to lesser speculation and the development of low-risk financial instruments (Arouri, Ben 

REVIEW

Ameur, Jawadi, Jawadi, \& Louhichi, 2013). By linking the participants, it is not possible, for example, to grant loans which are not required for a real transaction. Thus, credit growth is directly linked to real economic growth in Islamic banking (Ahmed, 2010).

Religions build the body for people's understanding of what is considered right or wrong. The religion's underlying values are often the basis for ethical behaviour (Parboteeah, Hoegl, \& Cullen, 2007). As the business model of Islamic banks relies on Islamic law, the Shariah, which depicts religious ideals, is often seen as having its own ethical identity. Primarily this results from the fact that the principles of Shariah were created not only to promote religious spirituality, but also to encourage social welfare and justice (Haniffa \& Hudaib, 2007). Islamic banks for instance also force social goals such as donating for charitable reasons as well as giving benevolent loans to socially disadvantaged people (Haniffa \& Hudaib, 2007). The religious basis on which the Islamic concept relies on significantly differs from a traditional economic perspective, which is often assumed to completely exclude social and ethical concerns in favour of profit maximisation and growth (Fang \& Foucart, 2013). Traditional banks today have the ability to undertake a wide range of activities including speculative operations to maximise their profitability. In order to cushion the associated high risks, regulators are becoming increasingly important which also enhances the transparency and ethical behaviour of the sector (Paulet, 2011). In addition, traditional banks have learned that their business not only depends on performance but also reputation plays a major role. If institutions respect and follow ethical rules, customer satisfaction increases which leads to further profits (Hossan Chowdhury, 2011). For the financial sector the difficulty lies in maintaining the balance between the various stakeholder's requirements (Mallin, Farag, \& OwYong, 2014). The aim of Islamic banks is a holistic integration of ethical, ecological and social concerns. This not only includes customers and the public, but must also be extended to the involved industries (Mohamad, 2014). In practice this means that companies which act as business partners of Islamic financial institutions should be restricted to cover any prohibited transactions and their business models must be in harmony with the Shariah's social, ethical and ecological goals (Mohamad, 2014). In times of persistent ecological problems, the whole financial sector should take responsibility and strive for sustainable development (Richardson, 2008).

The recent global financial crisis and the associated demand for sustainable alternatives compared to conventional banking explain and support the enormous growth rates mentioned before. Ethical and moral rules as well as the assumed higher risk awareness makes Islamic banking a good alternative not only in Muslim countries but it is also an emerging financial alternative in many western countries (Jawadi, Jawadi, \& Louhichi, 2014). However, not only the demand side has changed, the institutions themselves have set various actions to make Islamic ba(Dees, 2007)nking more attractive to the majority (Rethel, 2011). Nevertheless, few people have knowledge of the background of this rapidly growing industry (Ahmed, 2010). A major challenge in the western world in particular, is the continued scepticism towards the incorporation of religious issues in the economy (Fang \& Foucart, 2013). Current literature confirms this view, as a strong polarisation between supporters and sceptics can be recognised, which makes it difficult to get an objective view on Islamic banking and finance through literature research (Fang, 2014). Despite the relevance of this topic, very few articles have been published in top journals until now (Abdelsalam \& El-Komi, 2014).

Because of the variety of perspectives in current research, this article aims to cluster research priorities and to collect current findings through conducting a systematic literature review. An initial analysis of topics discussed in current literature shows that the emphasis lies on a wide range of different themes. Abedifar et al. for instance derive the competition of Islamic vs. conventional banks, the profit and loss-sharing behaviour as well as the various risks of Islamic banking as important topics (Abedifar, Ebrahim, Molyneux, \& Tarazi, 2014), 
whereas Khan questions the real purpose of Islamic banks in the case of social welfare versus the maximisation of profit (F. Khan, 2010).

To create a systematic literature review on Islamic banking and finance the authors carry out an in-depth analysis on existing journal articles and determines a number of exogenous research topics, which are depicted in Figure 1.

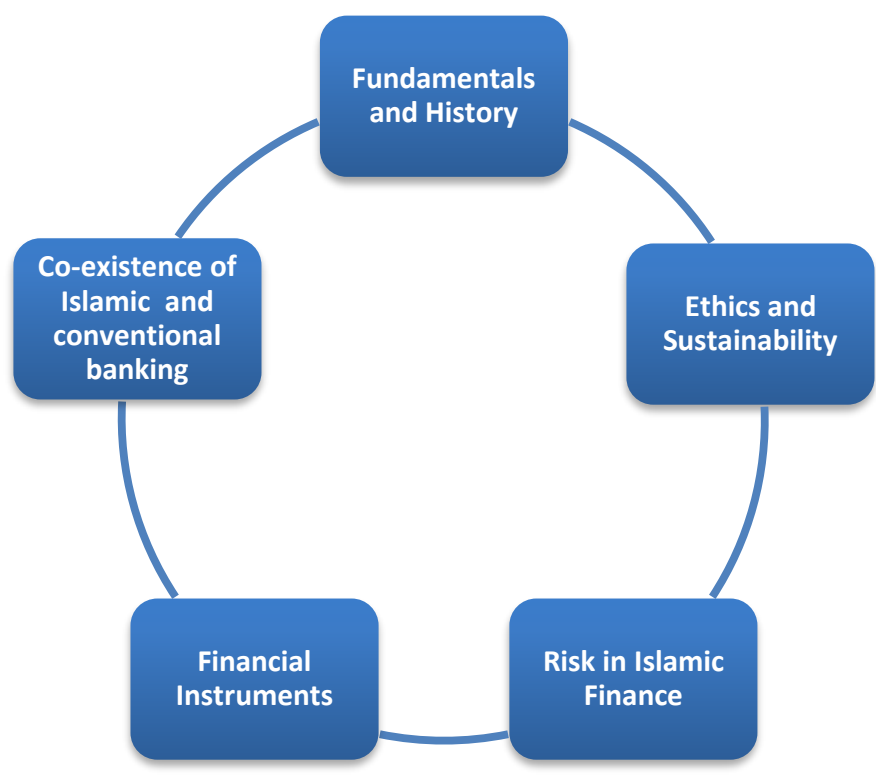

Figure 1: Structuring exogenous research topics (source: authors)

To roughly divide the analysed articles into central categories, coding was firstly carried out based on headlines and abstracts. Coding makes it easier for the researcher to summarise and structure the available data with the risk of neglecting relationships between the different categories (Denzin \& Lincoln, 2011). After the establishment of five central research topics (see Figure 1) the authors categorise the articles based on their content (Bryman, 2012). In order to define current research topics as well as relevant future issues, further coding was used on text passages within the articles. Depending on the number of authors that are already working on a particular topic, the geographical reach of research as well as the research methods used in the progress the state and relevance is divided into several ranges (state of current research: mature - intermediate - nascent / relevance for future research: high - medium - low) within the literature review.

The key topics intend to improve the structure of the systematic literature review based on a number of guiding questions. When selecting the guiding questions, it is important to notice that Islamic banking already takes high priority nowadays. As Khan points out, almost every major bank is represented in the sector by setting up separate Islamic banking branches (F. Khan, 2010). The study of Ernst \& Young underpins this and expects rapid growth rates in the coming years $(E Y, 2014)$. In addition, authors have identified different reasons why customers prefer Islamic banks. For example, Jawadi argues that the rapid growth of the sector is primarily based on the fact that ethical and moral rules are more important after the recent global financial crisis than religious concerns (Jawadi et al., 2014). Due to the wide range of opinions and authors in current research, the first guiding question is dedicated to the state of current academic research. In addition, the authors question the potential of Islamic banking and finance to serve as an ethical alternative. 
The rules of Islamic banking, which are specified by the Shariah, are known but the interpretation and implementation is still a controversially discussed issue. Taking the prohibition of interest as an example, Malik et al. see no explicit prohibition of interest in the Qur'an whereas Ghannadian and Goswami argue that only excessive interest rates should be prohibited (Ghannadian \& Goswami, 2004; Malik, Malik, \& Mustafa, 2011). Since inconsistencies and contradictions are observed in every key topic, the authors are also engaged in the various facets. Therefore, the next guiding question is about inconsistencies and contradictions.

As the authors demonstrate the relevance of the topics, it also seen as necessary to discuss the future of Islamic banking. While there are already many studies that deal with estimated growth in coming years, one does not know how this growth will affect the Islamic banking sector as well as the banking sector as a whole in the future. Not only the effects of growth need to be explored. Exemplarily hedging in Islamic finance can be mentioned as an important future issue. Due to the fact that risk elements are involved, hedging is traditionally forbidden in Islamic finance (Siddiqui, 2008). Nevertheless, future research may provide alternatives by developing new hedging instruments that comply with Shariah guidelines.

The selected guiding questions are summarised as follows:

- What is the state of current academic research?

- To what extent can Islamic banking be considered as an ethical alternative?

- Are there inconsistencies and contradictions?

- What can important future research areas be?

\section{Systematic Literature Review}

Despite the fact that there are many recent articles available on Islamic banking which is still considered to be a nascent research area, the topics researched are not clustered and have not yet been checked for relevance. Therefore, the authors perform a systematic literature review to define current research topics and to subsequently derive future research propositions. Figure 2 shows an excerpt of keywords used for online research. After performing the overall online research, the authors limit the articles found based on the importance of the journals, and only journal articles which were subjected to a double-blind peer review process before publication are used (see Table 1 for more information). The selection process ensures that the articles used are scientifically relevant in current Islamic banking research. The articles found are sorted by relevance. For this purpose, the ABS $4^{\text {th }}$ journal list is used as a basis. Due to the fact that Islamic banking and finance is still a niche topic, further non-ABS articles are added which are intended to complement the results. 
Table 1: List of reviewed journals (source: authors)

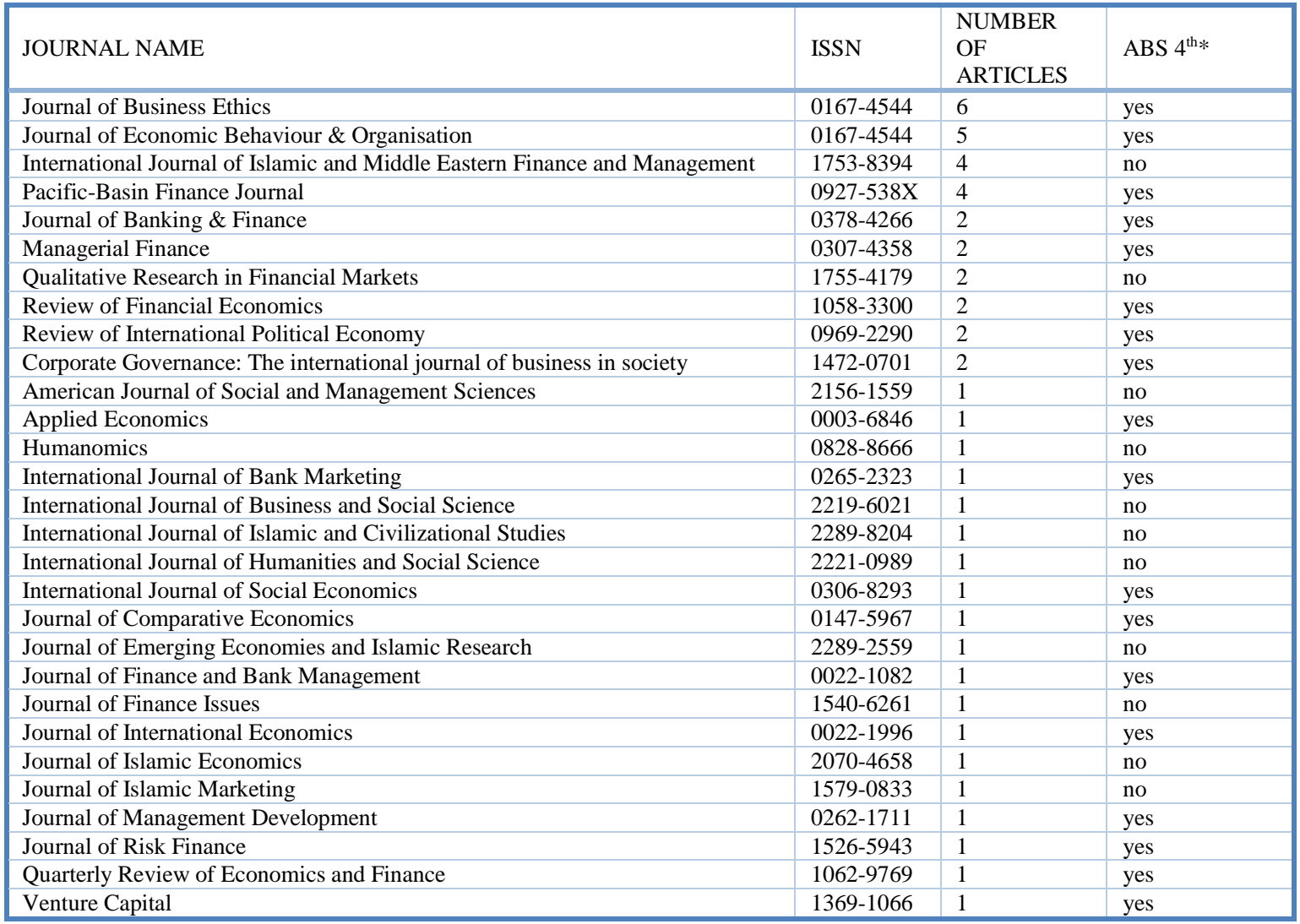

* Academic Journal Quality Guide Version 4 published by ABS - the Association of Business Schools (source: http://charteredabs.org/wp-content/uploads/2015/05/2010-Journal-Guide.pdf) 
ISLAMIC BANKING AND FINANCE AS AN ETHICAL ALTERNATIVE: A SYSTEMATIC LITERATURE REVIEW

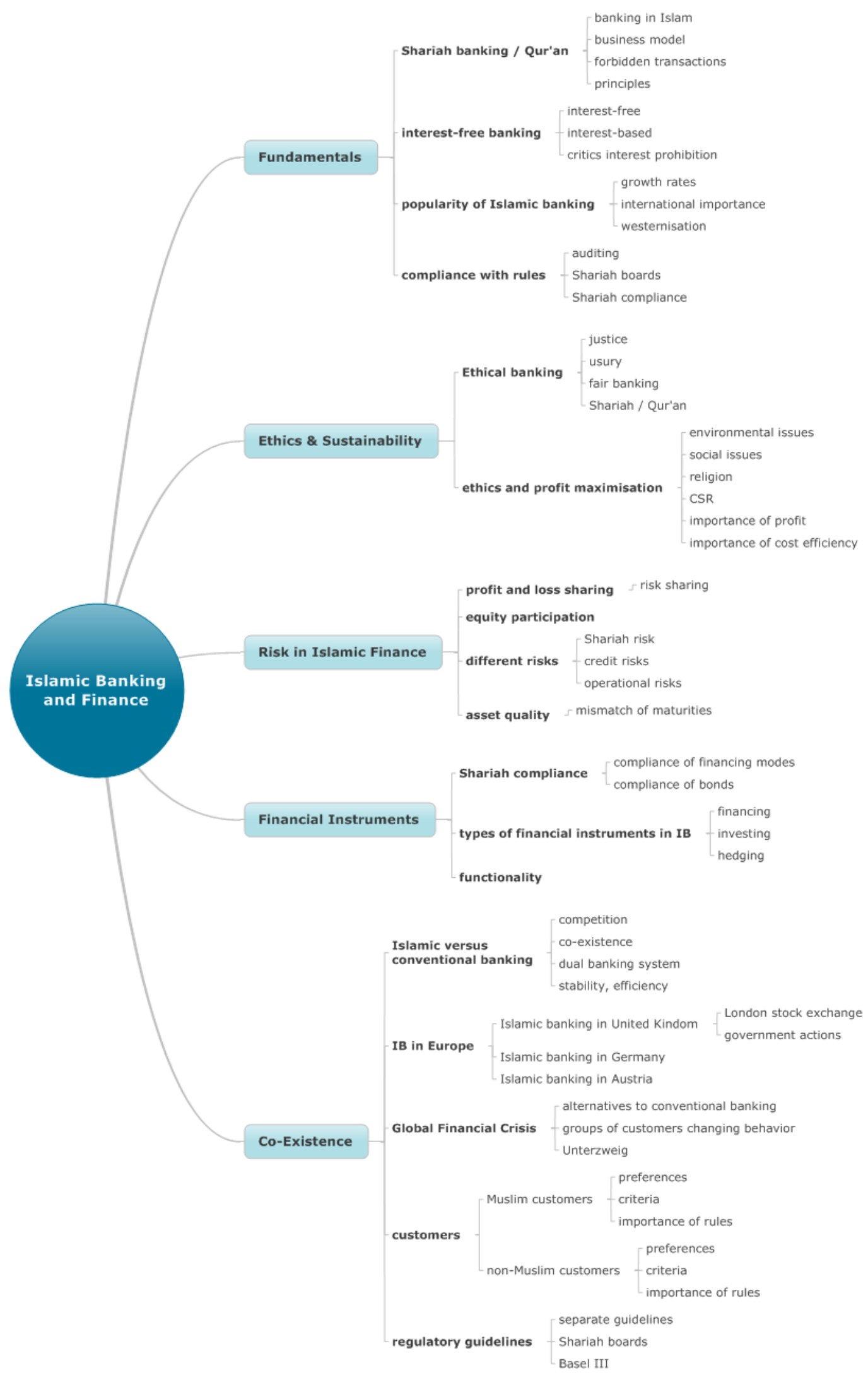

Figure 2: Summary of research keywords for Literature Review (source: authors) 
For the purpose of a better structure within the literature review, coding was used on the researched articles. The authors have identified five central topics as most relevant in relation to Islamic banking and finance (see also Figure 1):

- Fundamentals

- Ethics and Sustainability

- Risk in Islamic Finance

- Financial Instruments

- Co-existence of Islamic and Conventional Banking

Going back to Figure 1 the authors use further coding on subheadings and text passages to identify relevant endogenous topics linked to the central categories mentioned. Examples of these endogenous codes are listed in Table 2.

Table 2: Research topics -structuring endogenous codes (source: authors)

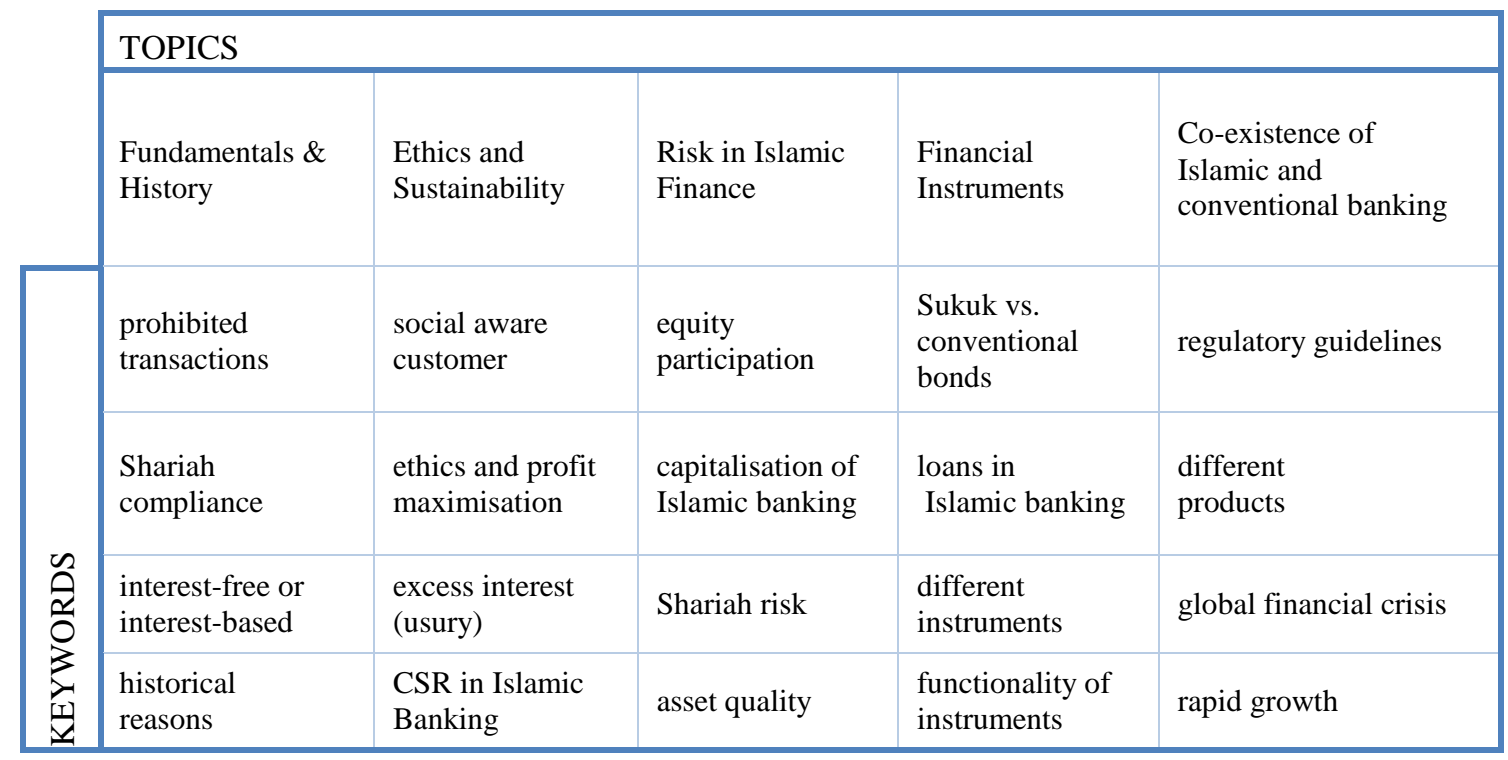

The sub-chapters 0 to 0 contain information about current research issues and trends. Additionally, the authors address contradictions within the literature. The main identified topics as well as the status of current research are subsequently summarised (e.g. Table 3). Furthermore, future research propositions are derived firstly out of the recommendations of the journal articles. Secondly, the authors involve topics that are almost never mentioned in current literature but seen relevant for further Islamic banking research. These future propositions are then summarised (e.g. Table 4). 

REVIEW

\section{Fundamentals}

Islamic law, the Shariah, as the foundation for the understanding of Islamic banking, implements religious views e.g. the teachings of the Qur'an into the judicature (Valeva, 2012). These teachings only allow a commercial transaction if it is free of interest (riba), uncertainty (gharar), gambling (maisir) and prohibited (non-halal) activities (Ariss, 2010).

Literature on the theoretical framework makes initial differences visible. Not all Muslims believe that the Qur'an explicitly forbids interest (Malik et al., 2011). Most Muslim scholars agree on the principle of avoiding interest while simultaneously reducing risk (Souaiaia, 2014). The Qur'ans riba is on the one hand equated with all forms of interest payments and on the other hand, only excessive forms of interest seem to be prohibited (Ghannadian \& Goswami, 2004). However, because the general understanding is based on a full prohibition of interest, Islamic banking relies on a profit and loss sharing principle instead (Mallin et al., 2014). Although the general conception prohibits interest, it is still possible to generate profits. The detail makes the difference as the investor does not know his expected return and has to accept more risk than a conventional investor (Perry \& Rehman, 2011).

The framework already provides room for contradictions, which appeared when reviewing current literature. While theory, respected by a huge number of authors, takes the principles for granted, Hamza or Khan, who have analysed Shariah banking and Shariah governance in Islamic countries through a qualitative study, demonstrate that compliance with Shariah rules and the sincerity of Islamic banking institutions is increasingly questioned (Hamza, 2013; F. Khan, 2010). This is also reflected in various other publications, particularly the purity of banking products and the honesty of acting persons are discussed issues (Haniffa \& Hudaib, 2007). An interesting paradox can be found when examining regulation issues. Jawadi et al. have investigated the financial performance of Islamic and conventional banks within the periods 2000 to 2011 in Europe, USA and the world and therefore define Islamic banking as highly regulated (Malik et al., 2011). Controversially, Malik et al. who have qualitatively analysed Islamic banking through performing a literature review, question the lack of uniform rules because of decentralised and individual Shariah boards (Jawadi et al., 2014). Not only researchers, but also Islamic scholars themselves differ in their conception (Gheeraert, 2014). On the one hand, Islamic banking is strictly isolated from conventional banking, on the other hand progressive scholars recommend the reinvention of conventional products with none or only little modifications (Beck et al., 2013; Mallin et al., 2014).

Surveys have shown that Shariah compliance plays an important role for customers in the Islamic banking sector in particular. The majority of Muslim customers would withdraw their deposits if the rules are not observed correctly (Ginena, 2014). In order to verify the required compliance, it is seen necessary to implement a regulatory body (Ginena, 2014). As previously mentioned, for this reason, various Shariah boards exist, which determine whether a product is Sharia compliant or not. These boards are a strongly criticised issue in current literature. Problems arise because of the fact that each region has its own supervisory bodies, which are not standardised (Perry \& Rehman, 2011). Another criticised point is that supervisory boards, like rating agencies which evaluate companies, provide a professional opinion about the Shariah compliance of a specific financial product or service and receive money in return (Azmat, Skully, \& Brown, 2014). This can lead to so-called fatwa shopping, in this connection banks use multiple boards to gain the confirmation of Shariah compliance for a product (Azmat et al., 2014). The objectivity of these individual boards is therefore increasingly questioned. Although global bodies like the AAOIFI and the IFSB exist, Hamza, for instance, notes that it is essential for the quality of future Islamic banking to set up an individual Shariah board, that does not receive any direct payments from the advised Islamic banks (Hamza, 2013; Mohamad, 2014). In this way, the objectivity and quality of the board concerning Shariah compliance can be ensured. 
Summing up the previously discussed research topics of this chapter, the following seem relevant:

Table 3: Current research topics - Fundamentals (source: authors)

\begin{tabular}{|l|l|l|}
\hline MAIN IDENTIFIED TOPICS & CORRESPONDING AUTHORS & STATE* \\
\hline \multirow{4}{*}{ status of interest in Islamic banking } & Souaiaia (2014) & \\
& Mallin et al. (2014) & + \\
& Malik et al. (2011) & \\
& Perry \& Rehman (2011) & \\
& Ghannadian \& Goswami (2004) & \\
& Gheeraert (2014) & \\
& Jawadi et al. (2014) & \\
& Mallin et al. (2014) & + \\
& Beck et al. (2013) & \\
compliance with Shariah rules & Hamza (2013) & \\
& Malik et al. (2011) & \\
& Khan (2010) & \\
& Haniffa \& Hudaib (2007) & \\
& Ghannadian \& Goswami (2004) & + \\
\hline \multirow{5}{*}{ audit possibilities } & Azmat et al. (2014) & \\
& Ginena (2014) & \\
& Mohamad (2014) & \\
\hline & Hamza (2013) & \\
& Perry \& Rehman (2011) & \\
\hline
\end{tabular}

*State: +++ mature / ++ intermediate $/+$ nascent

In summary, it can be stated that in addition to the general explanation of the fundamentals of Islamic banking the prohibition of interest is one of the most frequently discussed issues in current research. Authors disagree on how Qur'ans riba has to be defined. Malik, for instance, shows that some Muslims are not convinced of the general prohibition of interest whereas most Muslim scholars take the principle of interest prohibition for granted (Malik et al., 2011; Souaiaia, 2014). Further research is primarily focused on the honesty of Islamic banking institutions as well as compliance with Shariah rules (Hamza, 2013; Haniffa \& Hudaib, 2007; F. Khan, 2010). As Perry and Rehman and Azmat et al. pointed out in their research, the variety of boards and their non-uniform decisions regarding Shariah compliance of financial products make it especially necessary to unify the regulatory framework on a worldwide basis as well as to work with an international independent supervisory board (Azmat et al., 2014; Perry \& Rehman, 2011). In addition, the authors see conformity of Islamic banks in terms of Basel III as well as the countries legal differences important for future research, despite them being sparsely discussed in the literature (Lahrech, Lahrech, \& Boulaksil, 2014; Perry \& Rehman, 2011).

The following table intends to summarise future research propositions in order to underline the importance of the topics previously discussed.

Table 4: Future research propositions - Fundamentals (source: authors)

\begin{tabular}{|c|c|c|}
\hline MAIN IDENTIFIED TOPICS & CORRESPONDING AUTHORS & RELEVANCE** \\
\hline $\begin{array}{l}\text { improvement of regulatory framework } \\
\text { countries legal differences }\end{array}$ & $\begin{array}{l}\text { Azmat et al. (2014) } \\
\text { Perry \& Rehman (2011) }\end{array}$ & +++ \\
\hline $\begin{array}{l}\text { implementation of international } \\
\text { Shariah board }\end{array}$ & $\begin{array}{l}\text { Azmat et al. (2014) } \\
\text { Perry \& Rehman (2011) }\end{array}$ & +++ \\
\hline compliance with Basel standards & Lahrech et al. (2014) & ++ \\
\hline
\end{tabular}

*Relevance: +++ high / ++ medium / + low 

REVIEW

\section{Ethics and Sustainability}

Religions define the body for the understanding of what is right or wrong and teach people values that are often responsible for their ethical behaviour (Parboteeah et al., 2007). Every individual sets their own moral principles that distinguish between what is right or wrong. However, there is always a general opinion of how something should occur (Hossan Chowdhury, 2011). When talking about ethics in business or the financial sector in particular keywords such as truth, fairness and justice are mentioned in context with competition, social responsibility or corporate behaviour for example (Hossan Chowdhury, 2011).

A growing number of investors integrates social and environmental issues when making financial decisions (Richardson, 2008). Generally, people do not believe in the intentions of Corporate Social Responsibility (CSR) policies of several institutions and primarily see CSR efforts as part of a marketing strategy (Paulet, Parnaudeau, \& Relano, 2014). The global interest therefore strongly focuses alternative ways of investing and financing which aim to create social welfare and justice (Mohamad, 2014). Some banks have foreseen this development and once again focus on the core business of the sector. These so-called ethical banks first occured in the 1980s and concentrate on the collection of savings and the distribution of credits (Paulet et al., 2014). As Paulet points out in her article, ethical banks also analyse the social and environmental goals of their business partners and base their decision on whether or not to finance a project by consideration of the underlying target in terms of its social and ecological structure (Paulet, 2011).

Islamic banking, which is based on ethical and moral values attributable to the teachings of the Qur'an, also gives priority to ethical and social issues and therefore represents an alternative not only for Muslim people (Wajdi Dusuki, 2008). Non-Muslims also look for socially responsible investments. Trust, benevolence, justice and balance represent the pillars of Islamic business ethics (El Garah, Dsouli, Khan, \& Kakabadse, 2012). The global financial crisis in particular has forced people worldwide to question the traditional banking and finance sector (Paulet et al., 2014). This is seen as one reason for the worldwide rapid growth of the Islamic banking sector, which has already been described in chapter 0 (Ahmed, 2010). As mentioned before, many incidents in recent years, especially those connected to the global financial crisis have led to an increasingly critical attitude towards the traditional banking system. Although Markowitz' portfolio theory suggests that investors prefer portfolios with a maximum return while minimising their risks, ethical and religious issues can have an impact on these decisions (Abdelsalam, Duygun, Matallín-Sáez, \& Tortosa-Ausina, 2014). As an alternative, investors nowadays are able to choose Islamic banking. With its goal to enhance economic and social welfare, it is often seen as having its own ethical identity (Haniffa \& Hudaib, 2007). This results from the underlying Shariah objectives - justice, fairness and social balance - which take an important role within the framework (Wajdi Dusuki, 2008). Though Islamic banks are currently experiencing a boom due to their ethical guidelines, they need to focus on their customer's needs to remain competitive in the long-term. Studies examining customers in Pakistan the UK, the UAE as well as Malaysia, reveal that customers of Islamic banks not only choose their bank because of religious issues, selection criteria are for instance the brand, security and service quality issues as well as product prices (Ahmad, Rustam, \& Dent, 2011; Masood, Abdul Rehman, \& Masood, 2012; Wajdi Dusuki \& Irwani Abdullah, 2007). The primary role for Islamic banks is therefore to maintain a balance between satisfying customer's needs in terms of sufficient returns and reasonable prices as well as to meet their social responsibilities (Mallin et al., 2014). Unlike ethical banks, which are already thinking one step ahead, the underlying rules of the Shariah are not applied to screen the social, ethical and environmental objectives of Islamic bank's business targets (Mohamad, 2014). 
Closely linked to Shariah compliance themes mentioned in chapter 0 , current literature examines the question of whether ethics and justice really have this high significance in Islamic banking or if cost efficiency and profit maximisation play the major role within the industry (F. Khan, 2010). This assumption is primarily based on increasing competition within the Islamic banking sector as well as between Islamic banks and their conventional banking counterparts (Uppal \& Mangla, 2014). Many important banks are trying to make money with their seemingly Islamic products, by looking for Shariah boards that certify their non-conforming products. It is often found that the offered products are similar to conventional products, but more expensive and touted as Shariah compliant (F. Khan, 2010).

As discussed in detail, the following keywords intend to summarise the current research topics linked to ethics and sustainability in Islamic banking:

Table 5: Current research topics - Ethics and Sustainability (source: authors)

\begin{tabular}{|c|c|c|}
\hline MAIN IDENTIFIED TOPICS & CORRESPONDING AUTHORS & STATE* \\
\hline GFC and change in customer's behaviour & $\begin{array}{l}\text { Abdelsalam et al. (2014) } \\
\text { Mallin (2014) } \\
\text { Mohamad (2014) } \\
\text { Paulet et al. (2014) } \\
\text { Masood et al. (2012) } \\
\text { Ahmed et al. (2011) } \\
\text { Ahmed (2010) } \\
\text { Richardson (2008) } \\
\text { Wajdi Dusuki (2008) } \\
\text { Dusuki \& Abdullah (2007) }\end{array}$ & +++ \\
\hline CSR and ethics in the finance industry & $\begin{array}{l}\text { Mallin (2014) } \\
\text { Paulet et al. (2014) } \\
\text { Hossan Chowdhury (2011) } \\
\text { Wajdi Dusuki (2008) } \\
\text { Haniffa \& Hudaib (2007) }\end{array}$ & + \\
\hline ethics vs. profit maximisation & $\begin{array}{l}\text { Uppal \& Mangla (2014) } \\
\text { Khan (2010) }\end{array}$ & + \\
\hline
\end{tabular}

*State: +++ mature $/++$ intermediate $/+$ nascent

It can be summarised that the incidents of the last few years, especially the GFC, has forced investors to change their behaviour and think about ethics and sustainability also in relation to banking and finance decisions (Paulet et al., 2014). In this context, Islamic banks also apply as an attractive alternative to non-Muslims (Wajdi Dusuki, 2008). Not only Khan, but also Uppal and Mangla show in their research that whether the increasing competition in the sector is driving Islamic banks away from compliance with Shariah rules towards a profit maximisation strategy is being questioned more and more (F. Khan, 2010; Uppal \& Mangla, 2014). Since the teachings of the Qur'an consider justice and social welfare as most important, the future research topics concerning ethics and sustainability go hand in hand with fundamental research themes. The cited authors see genuine compliance with Shariah rules, not only to attract potential customers, as the most important objective in order to pursue the ethical goals of Islamic banking. Furthermore, it is seen necessary to research how the rapid growth of this segment affects the focus on profit maximisation. 
Table 6: Future research propositions - Ethics and Sustainability (source: authors)

\begin{tabular}{|l|l|l|}
\hline MAIN IDENTIFIED TOPICS & CORRESPONDING AUTHORS & RELEVANCE* \\
\hline & Abdelsalam et al. (2014) & \\
& Mallin (2014) & \\
& Mohamad (2014) & \\
& Paulet et al. (2014) & \\
& Uppal \& Mangla (2014) & \\
conformity with Shariah rules & Masood et al. (2012) & \\
& Ahmed et al. (2011) & + \\
& Ahmed (2010) & \\
& Khan (2010) & \\
& Richardson (2008) & \\
& Wajdi Dusuki (2008) & \\
& Dusuki \& Abdullah (2007) & \\
\hline ethics vs. profit maximisation in & Uppal \& Mangla (2014) & ++ \\
a growing market & Khan (2010) & ++ \\
\hline harmonisation of product performance and & Uppal \& Mangla (2014) & \\
ethics & Khan (2010) & \\
\hline
\end{tabular}

*Relevance: +++ high / ++ medium / + low

\section{Risk in Islamic Finance}

To be globally competitive and meet the required standards, e.g. Basel III or IFRS, it is critical to consider the unique risks and costs Islamic banking includes (Paldi, 2014).

In theory, due to the intended profit and loss sharing nature of Islamic finance contracts, profits can only be earned if a share of the risk is taken by every involved party (F. Khan, 2010). In every project, risk is shared among the investor and the entrepreneur, which means if a project is successful the involved parties share the profit, if not they share the losses too (Azmat et al., 2014). Unfortunately, there is a steady decrease in the use of profit and loss sharing (PLS) instruments of Islamic banks. Khan and Bhatti argue that policy makers in Islamic banks see bad loans, high risk potential and over-optimistic profit predictions in their financed projects. Furthermore the lack of standards and the high execution and monitoring expenses can be seen. Additionally, banks fear that savers will instantly withdraw their deposits as soon as PLS is introduced (M. Khan \& Bhatti, 2008a). El-Hawary et al. add that while regulatory requirements must be complied with, Islamic banks do not have the same extent of standardisation and risk management tools as conventional banks (El-Hawary, Grais, \& Iqbal, 2007). Thus Islamic banks are actually more bound to a risk transfer system like their conventional counterparts than to a Shariah compliant risk sharing system (Ibrahim \& Mirakhor, 2014). To become more 'Islamic' theoretical and empirical research on the possibilities of PLS usage seems to be increasingly important in the future (Azmat, Skully, \& Brown, 2015).

Although bankruptcy risk and credit risk can be reduced due to the adoption of profit and loss sharing instruments, there is a set of unique risks that should also be taken into account (Uppal \& Mangla, 2014). Related to this, another interesting paradox can be found in current literature. Perry and Rehman strongly criticise the bad capitalisation of Islamic banks when conducting their literature review on the globalisation of Islamic finance (Perry \& Rehman, 2011). On the contrary a quantitative study conducted by Beck et al. reveals that Islamic banks have better capitalisation and a better asset quality than their conventional equivalents which is marked positive, whereas a major risk lies in matching different maturities (Beck et al., 2013). Beck et al. examined 510 Islamic and conventional banks across 22 countries from 1995 to 2009 concerning their business orientation, efficiency, asset quality and stability (Beck et al., 2013). As the global financial crisis has recently shown, the mismatch of maturities can result in serious financial downturns (Malik et al., 2011). Islamic assets are usually of long-term maturity, while liabilities are mostly short-term which creates an ongoing liquidity risk to cope with (Malik et al., 2011; Paldi, 2014). A study published by Ginena points out that the so-called Shariah risk can also heavily compromise the efficiency of an Islamic bank (Ginena, 2014). As 
the main operational risk of an Islamic bank, Shariah risk means that a bank is not compliant with the underlying Sharia rules and therefore has the problem, that stakeholders and shareholders do not trust in the system anymore and will most likely withdraw their deposits (Ginena, 2014). However, Shariah risk can also be a sticking point, since the complexity of interpreting Islamic law may mask other important risks (Uppal \& Mangla, 2014).

The use of hedging instruments in Islamic finance represents a nascent research area. Due to the fact, that those instruments have risk elements (gharar) involved, they are traditionally forbidden in Islamic banking (Siddiqui, 2008). Unlike hedging in traditional banks, Islamic hedging instruments are used to mitigate real risks and not for speculation issues. For this reason they are not tradable like conventional derivatives (Mohamad, Othman, Roslin, \& Lehner, 2014). Mohamad et al. revealed two major challenges in Islamic hedging: As speculation is prohibited through the principles of the Shariah and hedging instruments have to comply with these principles, there are limited possibilities of hedging in Islamic banking. Secondly, Islamic banking institutions have to be able to provide alternative hedging solutions for their clients. The challenge therefore lies in developing new hedging instruments (Mohamad et al., 2014).

The keywords listed below summarise the previously discussed current research topics.

Table 7: Current research topics - Risk in Islamic finance (source: authors)

\begin{tabular}{|c|c|c|}
\hline MAIN IDENTIFIED TOPICS & CORRESPONDING AUTHORS & STATE* \\
\hline risk sharing in Islamic banking & $\begin{array}{l}\text { Azmat et al. (2015) } \\
\text { Azmat et al. (2014) } \\
\text { Ibrahim \& Mirakhor (2014) } \\
\text { Khan (2010) } \\
\text { Khan \& Batti (2008a) } \\
\text { El-Hawary et al. (2007) }\end{array}$ & ++ \\
\hline $\begin{array}{l}\text { risk types (liquidity risk, operational risk, } \\
\text { Shariah risk,...) }\end{array}$ & $\begin{array}{l}\text { Ginena (2014) } \\
\text { Paldi (2014) } \\
\text { Uppal \& Mangla (2014) } \\
\text { Beck et al. (2013) } \\
\text { Malik et al. (2011) } \\
\text { Perry \& Rehman (2011) }\end{array}$ & ++ \\
\hline hedging in Islamic finance & $\begin{array}{l}\text { Mohamad et al. (2014) } \\
\text { Siddiqui (2008) }\end{array}$ & + \\
\hline
\end{tabular}

*State: +++ mature $/++$ intermediate $/+$ nascent

Although Shariah prescribes profit and loss sharing in Islamic banking, PLS instruments are decreasingly used by most Islamic banks. As Khan and Bhatti pointed out in their research this primarily results from the risks and expenses covered by PLS usage (M. Khan \& Bhatti, 2008a). In future, it will therefore be important to conduct intense research in this area. As Ibrahim and Mirakhor state in their article, this is necessary to bring Islamic banks away from a risk transfer system towards a Shariah compliant profit and loss sharing system (Ibrahim \& Mirakhor, 2014).

Furthermore, enhanced efforts need to be set to improve risk management to be more Shariah compliant and to meet the existing and upcoming regulatory requirements. Particular attention should be paid to the matching of maturities as well as Shariah risk as the main operational risk for Islamic banking institutions (Beck et al., 2013; Ginena, 2014).

As previously described, Islamic hedging will be an important research area in the future, as it is a nascent area at present. Mohamad et al. emphasise that this importance is mainly due to the limited possibilities of hedging in Islamic banking as all sorts of speculation are prohibited (Mohamad et al., 2014). It will therefore be important to generate new ideas to be able to offer alternative hedging solutions for Islamic banking customers. 
Table 8: Future research propositions - Risk in Islamic finance (source: authors)

\begin{tabular}{|l|l|l|}
\hline MAIN IDENTIFIED TOPICS & CORRESPONDING AUTHORS & RELEVANCE* \\
\hline \multirow{4}{*}{ from risk transfer to real risk sharing } & Azmat et al. (2015) & \\
& Azmat et al. (2014) & \multirow{2}{*}{ Ibrahim \& Mirakhor (2014) } \\
& Khan (2010) & ++ \\
& Khan \& Batti (2008a) & \\
& El-Hawary et al. (2007) & \\
compliance of risk management with Shariah & Ginena (2014) & Ibrahim \& Mirakhor (2014) \\
AND regulatory requirements & Beck et al. (2013) & ++ \\
& Khan (2010) & \\
& Siddiqui (2008) & \\
\hline \multirow{2}{*}{ Islamic hedging tools } & Mohamad et al. (2014) & \\
& Siddiqui (2008) & +++ \\
\hline
\end{tabular}

*Relevance: +++ high / ++ medium / + low

\section{Financial Instruments}

Islamic banking financial instruments are a comprehensively discussed issue due to the underlying principles of interest prohibition (riba) as well as the forbiddance of risk (gharar) and gambling (maisir) (Siddiqui, 2008). Due to the variety of financial instruments in Islamic banking, only a small part is discussed in this section of the article.

The most relevant topics currently deal with the debt-financing side in Islamic banking. Since Islamic banking is based on the principle of profit and loss sharing, typical financing modes in theory are for example Musharakah and Mudarabah (Chong \& Liu, 2009). While Musharakah implies complete profit and loss sharing, Mudarabah is based upon profit sharing only (Shamsudin, Salamon, \& Abu-Hussin, 2014). In Mudarabah thus the bank provides the entire capital and is financially involved in the success of the whole project (Chong \& Liu, 2009). Uppal and Mangla, who examine the asset structure of Islamic and conventional banks in the MENA region in the years 2006 to 2010, demonstrate in their article that almost no PLS financing is practiced in Islamic banks up to date (Uppal \& Mangla, 2014). The most widely used form of financing is Murabaha. In Murabaha, the bank owns the financed product, which is then transferred to the customer. The bank therefore bears the full risk for a short period of time (Rethel, 2011). Although both profit and loss sharing as well as mark-up financing modes like Murabaha are allowed by almost every Islamic banking scholar, mark-up financing is a heavily criticised issue in current literature (Shamsudin et al., 2014). Authors agree that Muharaba financing violates the principles of Shariah, as it is inspired by interest-based financing of conventional banks and contains a type of risk for the bank itself (Azmat et al., 2014; Shamsudin et al., 2014; Siddiqui, 2008; Uppal \& Mangla, 2014). As investment instruments, primarily Sukuk - Islamic bonds - are available with the same configurations, the topic of Shariah compliance is also apparent on the investment side (Azmat et al., 2014; Godlewski, Turk-Ariss, \& Weill, 2013).

The structure of Sukuk is comparable with conventional bonds, whereas Sukuk have to be strictly placed in conformity with Shariah principles. Godlewski et al. define three criteria for Sukuk to be Shariah compliant: (1) representation of ownership in tangible assets (2) investors should receive payments from after-tax profits (3) the redemption value must match the actual market price and not the amount invested (Godlewski et al., 2013). According to these criteria, authors agree that there is a noticeable lack of Shariah compliance, because at least one of those principles is violated most of the time (Azmat et al., 2014; Godlewski et al., 2013; Malik et al., 2011). Current studies are primarily pondering the question of whether the performance of Sukuk or conventional bonds is better. Jawadi et al., who have empirically investigated the performance of Islamic and conventional indexes in three regions (the world, the USA and Europe) in the periods 2000 to 2011, suggest that in turbulent times Sukuk perform better 
(Jawadi et al., 2014). On the contrary, conventional bonds seem to be more successful in calm periods (Jawadi et al., 2014). Godlewski et al. who have researched on the issuance of Sukuk and conventional bonds in the years 2002 to 2009, claim that Sukuk issues trigger negative market reactions. Investors connect less-healthy companies with low profit expectations to Sukuk whereas better companies are connected to conventional bonds issuance (Godlewski et al., 2013).

The following keywords precisely summarise current research themes concerning financial instruments in Islamic banking, as previously discussed.

Table 9: Current research topics - Financial instruments (source: authors)

\begin{tabular}{|c|c|c|}
\hline MAIN IDENTIFIED TOPICS & CORRESPONDING AUTHORS & STATE* \\
\hline financing structure of Islamic banks & $\begin{array}{l}\text { Azmat et al. (2014) } \\
\text { Shamsudin et al. (2014) } \\
\text { Uppal \& Mangla (2014) } \\
\text { Godlewski et al. (2013) } \\
\text { Rethel (2011) } \\
\text { Chong \& Liu (2009) } \\
\text { Siddiqui (2008) }\end{array}$ & +++ \\
\hline bond compliance & $\begin{array}{l}\text { Azmat et al. (2014) } \\
\text { Godlewski et al. (2013) } \\
\text { Malik et al. (2011) }\end{array}$ & ++ \\
\hline Sukuk performance & $\begin{array}{l}\text { Jawadi et al. (2014) } \\
\text { Godlewski et al. (2013) }\end{array}$ & + \\
\hline
\end{tabular}

Summing up this chapter, Shariah compliance is a major issue when looking at current research concerning financial instruments in Islamic banking. As already mentioned in chapter 0 , profit and loss sharing instruments only represent a very small part on both financing and investment side of Islamic banks. For example Murabaha financing is criticised by Shamsudin et al. because it is interest-based although the Shariah strictly forbids riba and therefore operational risks also occur for Islamic banks (Shamsudin et al., 2014). On the investment side, Islamic bonds called Sukuk are criticised regarding Shariah compliance and PLS usage too (Godlewski et al., 2013). Due to the fact that investors see Sukuk negatively because they link less-healthy companies with Sukuk issuance, as the study from Godlewski et al. revealed, it is important to do further research on Sukuk performance to shed light on the uncertainties of potential customers (Godlewski et al., 2013). However, not only financing and investment instruments have to be revised to comply with Shariah standards. The authors also see potential for further research in the area of derivatives in Islamic banking as only a few articles concerning this topic have been published as of yet. 
Table 10: Future research propositions - Financial instruments (source: authors)

\begin{tabular}{|l|l|l|}
\hline MAIN IDENTIFIED TOPICS & CORRESPONDING AUTHORS & RELEVANCE* \\
\hline \multirow{4}{*}{$\begin{array}{l}\text { implementation of PLS and long-term } \\
\text { instruments }\end{array}$} & $\begin{array}{l}\text { Azmat et al. (2014) } \\
\text { Shamsudin et al. (2014) } \\
\text { Uppal \& Mangla (2014) } \\
\text { Godlewski et al. (2013) } \\
\text { Rethel (2011) } \\
\text { Chong \& Liu (2009) } \\
\text { Siddiqui (2008) }\end{array}$ & +++ \\
\hline improvement of reputation (e.g. Sukuk) & $\begin{array}{l}\text { Jawadi et al. (2014) } \\
\text { Godlewski et al. (2013) }\end{array}$ & \\
\hline derivatives in IBF & $\begin{array}{l}\text { Mohamad et al. (2014) } \\
\text { Siddiqui (2008) }\end{array}$ & + \\
$*$ Relevance: +++ high / ++ medium / + low & & ++ \\
\hline
\end{tabular}

\section{Co-existence of Islamic and conventional banking}

The recent financial crisis was a global challenge and has tested the resilience of the banking sector as a whole (Bourkhis \& Nabi, 2013). Beck et al., who empirically analysed the business model, efficiency and stability of Islamic and conventional banks, found in their study that due to a better capitalisation and a higher asset quality, Islamic banks outperform conventional banks in terms of crisis (Beck et al., 2013). Chong and Liu, who have researched the Islamic banking system in Malaysia support this view and argue that risk sharing and PLS instruments help Islamic banks to absorb shocks better than their conventional counterparts (Chong \& Liu, 2009). The problem of excess liquidity, which appears to be due to the used financial instruments of Islamic banks, additionally supports the view of Islamic banks improved performance in crisis periods. By this originally negative excess liquidity, shocks can be intercepted more easily (M. Khan \& Bhatti, 2008a). Conversely, a study on the financial soundness of Islamic banks relatively to those of conventional banks between 1998 to 2009 by Bourkhis and Nabi points out that the soundness of both banking types does not differ significantly in crisis periods (Bourkhis \& Nabi, 2013). The business model of Islamic banks is mainly driven by the underlying principles of the Islamic religion. This implies that compared to conventional banks, lived religious values differ them from their competitors in the conventional sector (Wajdi Dusuki, 2008). Researchers agree that the asset quality of Islamic banks is higher, however there is disagreement about the efficiency of Islamic banks (Beck et al., 2013; Johnes, Izzeldin, \& Pappas, 2014). Khan points out doubtfully, that the only difference between a conventional and an Islamic financial instrument is "Shariah arbitrage", which means that one must find a suitable Arabic name for the same product and has to use it in comparison with Shariah principles (F. Khan, 2010).

Islamic finance has increased its significance in recent years. This is partly due to the double-digit annual growth rates within the sector (see also chapter 0). In non-Muslim countries, growth is estimated to be even higher, Fang and Foucart quote that in 2012 to 2013 a sensational overall growth rate of $37.5 \%$ was measured in non-Muslim countries (Fang \& Foucart, 2013). The rapid growth of Islamic banking has led to a dual banking system in many areas of the world, whereas both Islamic banks and conventional banks own market shares and therefore co-exist (Abedifar, Hasan, \& Tarazi, 2014). In addition to Islamic banks, the phenomenal growth as well as the need for innovation has also attracted the interest of international conventional banks which implies more competition within the Islamic sector (Hassan, Chachi, \& Latiff, 2008). International banks today are offering their own Islamic products and have often have set up their own Islamic banking windows like HSBC or Citibank did for example (Uppal \& Mangla, 2014). Islamic banks are therefore forced to compete with both, Islamic and conventional competitors (Hassan et al., 2008). New established Islamic banks often have to offer more competitive services in order to survive within their own branch (Malik et al., 2011). There is no agreement on how strong the competition from Islamic 
windows of conventional banks really is. Ariss argues, that Islamic banks internationally compete with each other, whereas Islamic windows of conventional banks do not compete because the serve a different market share (Ariss, 2010). However, a study questioning Muslim and non-Muslim bank customers in the UK published by Mansour et al. shows that even for Muslim customers 'low services charges' is the most important selection criterion and 'religion' is only placed on second rank (Mansour, Ben Abdelhamid, Masood, \& Niazi, 2010). This implies that both types of banks are in competition with each other. Contrary to this, Chong and Liu researched the dual banking system of Malaysia as a positive example, which managed to depose regulations so that both sectors can successfully exist side-by-side (Chong \& Liu, 2009). Gheeraert concludes that the co-existence of both scholars leads to an ideal market situation, where both conventional and Islamic banking, act as complements to each other (Gheeraert, 2014). Although customers can maintain business relationships with both types of banks, it is considered important that both segments are separated particularly in terms of regulations (Ariss, 2010).

Certain milestones were reached, such as the opening of the first European Islamic bank in Luxembourg in 1978, in addition to the first Sukuk issuance in Germany in 2004, to set sail for Islamic banking in Europe (Perry \& Rehman, 2011). The United Kingdom emerged as the most advanced market for Islamic banking and finance within Europe. This is not only attributable to London as the financial centre, as the London stock exchange is also very popular for Sukuk listings. Likewise the British government is responsible for a lot of support. To satisfy the high amount of Muslim population within the country, the government took several actions that paved the way for Islamic banking in the UK (di Mauro et al., 2013; Mansour et al., 2010). The abolishment of double taxation (e.g. land transfer taxes) for instance eased the execution of Islamic mortgage contracts and reduced costs for Islamic banking customers, which made it possible to offer Islamic banking products competitively (M. Khan \& Bhatti, 2008b).

Summing up the discussed topics concerning the co-existence of Islamic and conventional banks, the current research topics can be categorised as follows:

Table 11: Current research topics - Co-existence (source: authors)

\begin{tabular}{|c|c|c|}
\hline MAIN IDENTIFIED TOPICS & CORRESPONDING AUTHORS & STATE* \\
\hline performance in different economic periods & $\begin{array}{l}\text { Johnes et al. (2014) } \\
\text { Bourkhis \& Nabi (2013) } \\
\text { Khan (2010) } \\
\text { Chong \& Liu (2009) } \\
\text { Khan \& Bhatti (2008a) } \\
\text { Wajdi Dusuki (2008) }\end{array}$ & +++ \\
\hline dual banking system & $\begin{array}{l}\text { Abedifar et al. (2014b) } \\
\text { Gheeraert (2014) } \\
\text { Uppal \& Mangla (2014) } \\
\text { Fang \& Foucart (2013) } \\
\text { Malik et al. (2011) } \\
\text { Ariss (2010) } \\
\text { Mansour et al. (2010) } \\
\text { Chong \& Liu (2009) } \\
\text { Hassan et al. (2008) }\end{array}$ & ++ \\
\hline Islamic banking in Europe & $\begin{array}{l}\text { Di Mauro et al. (2013) } \\
\text { Perry \& Rehman (2011) } \\
\text { Mansour et al. (2010) } \\
\text { Khan \& Bhatti (2008b) }\end{array}$ & + \\
\hline
\end{tabular}

*State: +++ mature / ++ intermediate / + nascent 

REVIEW

Holistically, current research on the co-existence of Islamic and conventional banking focuses on similarities and differences between the two sectors. Tested issues are mainly the efficiency and stability as well as the asset quality of Islamic and conventional banks in different economic periods. Despite the confirmed higher asset quality and liquidity of Islamic banks, authors disagree on which model is more crisis-proof (Beck et al., 2013). The competition within the Islamic banking sector and between Islamic and conventional banks is growing, as international banks see profit potential due to high annual growth rates. Mansour et al. also highlight that Muslim customers would switch to conventional banks because today, 'religion' is not the only important selection criterion (Mansour et al., 2010). Although both types are in competition with each other Gheeraert declares that both types complementing each other will lead to an ideal market situation (Gheeraert, 2014). Prospectively, future research should focus on regulatory guidelines to manage the rapid growth and competition. In many regions of the world, uniform guidelines like Basel III are used for the whole banking sector which are often not adoptable to Islamic banking (Perry \& Rehman, 2011). It is questionable whether a uniform system is useful to regulate the Islamic and the conventional sector as a whole (Ariss, 2010). Another approach may be separate regulations aimed to focus on peculiarities such as the underlying Shariah principles as well as the risk profile and the asset structure of the different banking types (Perry \& Rehman, 2011). In relation to the rapid growth the authors examine the development of Islamic banking within Europe. As mainly the UK plays a leading role, it will be important to apply the lessons learned to other countries within Europe and to supplement these findings with reasonable regulatory adjustments.

Table 12: Future research propositions - Co-existence (source: authors)

\begin{tabular}{|l|l|l|}
\hline MAIN IDENTIFIED TOPICS & CORRESPONDING AUTHORS & RELEVANCE* \\
\hline unified vs. individual regulatory & Gheeraert (2014) & \\
framework & Perry \& Rehman (2011) & ++ \\
& Ariss (2010) & \\
& Abedifar et al. (2014b) & \\
& Gheeraert (2014) & \\
& Uppal \& Mangla (2014) & \\
& Fang \& Foucart (2013) & Malik et al. (2011) \\
impact of competition & Ariss (2010) & ++ \\
& Mansour et al. (2010) & \\
& Chong \& Liu (2009) & \\
& Hassan et al. (2008) & \\
\hline \multirow{2}{*}{ UK - a shining example? } & Di Mauro et al. (2013) & \\
& Perry \& Rehman (2011) & Mansour et al. (2010) \\
& Khan \& Bhatti (2008b) & ++ \\
*Relevance: +++ high / ++ medium / + low & \\
\hline
\end{tabular}




\section{Discussion}

The first question asked about the state of current academic research concerning Islamic banking and finance, and a variety of topics amongst the subject of Islamic banking fundamentals came up. It is noticeable that a lot of research has already been carried out and the theoretical framework is mistakenly taken for granted, although there are still many inconsistencies and contradictions within the literature. For instance, the interpretation of the Qur'an on the subject of prohibition of interest varies widely (Ghannadian \& Goswami, 2004; Souaiaia, 2014). The authors admit that, considering the thought of profit and loss sharing, a general prohibition of interest would be desirable. However, in the opinion of the authors, different interpretations are also due to the pursuit of profit maximisation of Islamic banking institutions. Not all researchers are of an equal opinion when analysing the previously applicable regulations, discussions are mainly focussed on the interpretation of certain prohibitions as well as the implementation of the principles in practice (Hamza, 2013; F. Khan, 2010). Authors are currently focusing their research on regulation issues. The main topics explored are compliance with Shariah rules as well as their assessment (Jawadi et al., 2014). The author's opinion is that the implementation of uniform rules in particular complying with the Shariah as well as the generation of an authority, which is responsible for checking compliance with these rules, must be given priority in future research. In addition, Basel III criteria should be included to a certain extent also for Islamic institutions (Lahrech et al., 2014).

Another focus is currently placed on research of the reasons for the enormous growth rates over recent years. The impact of the global financial crisis and thus the changing customer behaviour is investigated. Additionally religious issues as well as ethical and moral preferences are considered. Decision-making criteria today also include reasons such as safety, service quality, product prices and brand awareness (Ahmad et al., 2011; Masood et al., 2012; Wajdi Dusuki \& Irwani Abdullah, 2007). In order to remain competitive and increase market share in the future, the authord consider these factors as increasingly important to satisfy customers. The authors also see the honesty of Islamic banking institutions as crucial factor for customer loyalty. The co-existence of both, Islamic banks and their conventional counterparts, leads to higher competition and therefore different banks will struggle for higher market shares in the future (Hassan et al., 2008). Researchers are actually focusing on finding out which similarities the two competing models have and to what extent Islamic banks are more crisis-proof than their counterparts (Beck et al., 2013; Johnes et al., 2014; F. Khan, 2010). Furthermore, researchers are contemplating whether a dual banking system would lead to an ideal market situation (Gheeraert, 2014). In this context, the expansion of Islamic banking in Europe is to be mentioned that is not yet advanced. Some countries such as the UK act as pioneers, which is not least through their legislative amendments that pave the way for Islamic banking in Europe (Mansour et al., 2010). The authorssee it necessary to take these pioneers as a model to enforce legal changes in other countries and thus make Islamic banking present in Europe. Furthermore, the focus has to be set on reducing the scepticism against Islamic banking and finance in the western world through specifically informing people about Islamic banking.

Religion goes hand in hand with ethics. The religious attitude of people subsequently defines what someone perceives as right or wrong. The religion thereby influences the moral principles of an individual that define ethical behaviour to a certain extent (Hossan Chowdhury, 2011). In this paragraph, the authors discuss some major paradoxes, synergetic findings and the relevance of it all for ethical findings. As an alternative, ethical banks that concentrate on the collection of savings and the provision of credits, were already created in the 1980s (Paulet et al., 2014). Since the beginning of the global financial crisis investors have been paying even higher attention to ethics within the financial sector. In addition to prioritising their core business, ethical banks in contrast to Islamic banks intensively focus on the business model of 
their partners. For example, a project will only be financed if the underlying target was classified as credible with regard to social and environmental concerns i.e. seems ethical correct (Paulet, 2011). The author's opinion is that Islamic banking is still far away from a holistic implementation of ethical guidelines. Environmental concerns are actually not involved in investment and financing decisions. For the authors it is striking that, despite strict selection of the underlying asset in case of financing and investing, no attention is paid to the business area of the underlying target. Therefore, whether or not the target acts ecologically sustainable is not controlled.

However, by forcing social issues such as donation or the granting of benevolent loans Islamic banks show that ethical and moral goals take high priority due to the origins based on the Qur'an (Haniffa \& Hudaib, 2007). Even for typical investors Islamic banking is becoming more attractive because of recent financial downturns. Nowadays investors not only make financial decisions to retrieve a high return or have a minimum risk, they also consider ethical issues (San-Jose, Retolaza, \& Gutierrez-Goiria, 2011). This fact increases the profit potential of Islamic banks. The authors question the real purpose of Islamic banks with regards to ethical and moral themes. Are Islamic banks really focussed on ethical and moral principles not only because of their underlying principles but also because of the importance of these topics today, or is this a strategy to maximise profit and attract the attention of potential customers?

According to the author, within the banking sector religious and ethical topics are moving further into the background in favour of profit maximisation and customer acquisition. An influence is for example possible by an increasingly higher regulation of the sector. Regulators like Basel III reduce risk and are able to influence the moral acting of the sector as a whole (Paulet, 2011). In the opinion of the author, a general rethink in the industry can only take place if customers pay even more attention to ethical and social issues when choosing their bank. As customer satisfaction also brings profit maximisation, banks will therefore automatically change their priorities (Paulet, 2011).

Moreover, authors deal with risk management and risk types in Islamic banking. Current literature is primarily on the problem of mandatory PLS usage, which is rarely availed by Islamic banks today (Azmat et al., 2015). Researchers see problems in the use of PLS mainly due to the high risk potential, the lack of standards as well as the high execution and monitoring expenses. As individual risk for Islamic banks liquidity risks can be seen, which are mainly due to the lack of matching maturities, but also the risk of non-compliance with the Shariah, which is highly valued (Ginena, 2014). Representing a nascent research idea, Islamic hedging instruments are controversially discussed in current literature. Although they are traditionally forbidden through Islamic law, the authors see the need for further research on this topic. Hedging instruments are not only used for speculation, but also for hedging and therefore minimising risks. In order to remain competitive, Islamic banks must also be able to provide equivalent products to their customers without violating Shariah guidelines.

The disclosure of future research priorities represented the last research area. According to the author, the highest priority should be given to the following topics:

- improvement of regulatory framework / implementation of regulatory body

- conformity with Shariah rules

- holistic implementation of ethical guidelines

- PLS usage (on financing and investment side) / matching of maturities

- derivatives / Islamic hedging tools

- westernisation of Islamic banking 


\section{Conclusion and Forecast}

This article serves to provide an insight into current research on the subject of Islamic banking and finance. In this context, the authors conduct a systematic literature review in order to define important research topics through a well validated coding process. Among the specified topics (see also Figure 1), current research areas are analysed. In a next step, inconsistencies and contradictions within the literature are discussed. Out of the results of the literature review, future research propositions are finally elaborated on. The article demonstrates that a lot of literature on Islamic banking already exists, but only a small part is actually represented in topjournals until now.

Taking the gaps and inconsistencies into consideration shows that there is need for action especially on the regulatory basis. The rapid growth of the industry as well as the different regional Shariah boards lead to different interpretations of the underlying guidelines. This implies that the compliance with Shariah guidelines cannot be assured and thus customers lose confidence in Islamic banking institutions. As part of the revision of the regulations, it should also be possible to lay down uniform rules concerning prohibition of interest as well as the use of PLS instruments. Structural considerations regarding the current problem of maturity matching in the books of Islamic banks should go hand in hand with the establishment of common rules. Researchers are challenged to develop new financial instruments that support the matching of maturities and satisfy customers, but also comply with Shariah guidelines.

Regarding the principles of the Shariah, Islamic banking with its underlying social and ethical goals is able to serve as an ethical alternative within the banking sector. For this reason, the authors deem it necessary to create a strict set of rules that prohibits circumvention of Shariah principles. An independent board must monitor these rules and impose sanctions for violation. Despite the existing ethical principles, Islamic banks have to encourage further development in this area. When selecting business partners as financing and investment targets, non-Shariah compliant transactions are rejected but for example ecological concerns are not yet taken into account (Mohamad, 2014). The financial sector and Islamic banks with their religious and ethical ideals in particular thus should strive for more sustainable development within the finance sector (Richardson, 2008).

\section{References}

Abdelsalam, O., Duygun, M., Matallín-Sáez, J. C., \& Tortosa-Ausina, E. (2014). Do ethics imply persistence? The case of Islamic and socially responsible funds. Journal of Banking \& Finance, 40, 182-194. doi:10.1016/j.jbankfin.2013.11.027

Abdelsalam, O., \& El-Komi, M. (2014). Islamic Finance: An Introduction. Journal of Economic Behavior \& Organization, 103, 1-3. doi:10.1016/j.jebo.2014.03.019

Abedifar, P., Ebrahim, S., Molyneux, P., \& Tarazi, A. (2014). Islamic Banking and Finance: Recent Empirical Literature and Directions for Future Research. HAL archives-ouvertes, 1-29. doi:hal-01073185

Abedifar, P., Hasan, I., \& Tarazi, A. (2014). Finance-Growth Nexus and Dual Banking System: Relative Importance of Islamic Banks. HAL archives-ouvertes, 39.

Ahmad, K., Rustam, G. A., \& Dent, M. M. (2011). Brand preference in Islamic banking. Journal of Islamic Marketing, 2(1), 74-82. doi:10.1108/17590831111115259

Ahmed, A. (2010). Global financial crisis: an Islamic finance perspective. International Journal of Islamic and Middle Eastern Finance and Management, 3(4), 306-320. doi:10.1108/17538391011093252

Ariss, R. T. (2010). Competitive conditions in Islamic and conventional banking: A global perspective. Review of Financial Economics, 19(3), 101-108. doi:10.1016/j.rfe.2010.03.002

Arouri, M. E., Ben Ameur, H., Jawadi, N., Jawadi, F., \& Louhichi, W. (2013). Are Islamic finance innovations enough for investors to escape from a financial downturn? Further evidence from portfolio simulations. Applied Economics, 45(24), 3412-3420. doi:10.1080/00036846.2012.707776 
Azmat, S., Skully, M., \& Brown, K. (2014). The Shariah compliance challenge in Islamic bond markets. PacificBasin Finance Journal, 28, 47-57. doi:10.1016/j.pacfin.2013.11.003

Azmat, S., Skully, M., \& Brown, K. (2015). Can Islamic Banking Ever Become Islamic? Pacific-Basin Finance Journal. doi:10.1016/j.pacfin.2015.03.001

Beck, T., Demirgüç-Kunt, A., \& Merrouche, O. (2013). Islamic vs. conventional banking: Business model, efficiency and stability. Journal of Banking \& Finance, 37(2), 433-447. doi:10.1016/j.jbankfin.2012.09.016

Bourkhis, K., \& Nabi, M. S. (2013). Islamic and conventional banks' soundness during the 2007-2008 financial crisis. Review of Financial Economics, 22(2), 68-77. doi:10.1016/j.rfe.2013.01.001

Bryman, A. (2012). Social Research Methods, 4th Edition (4 ed. Vol. 4). Oxford: Oxford University Press.

Chong, B. S., \& Liu, M.-H. (2009). Islamic banking: Interest-free or interest-based? Pacific-Basin Finance Journal, 17(1), 125-144. doi:10.1016/j.pacfin.2007.12.003

Dees, J. (2007). Taking Social Entrepreneurship Seriously. Transaction Society, 44(3), 1-8.

Denzin, N. K., \& Lincoln, Y. S. (2011). The SAGE Handbook of Qualitative Research (Vol. 4). London: SAGE Publications Ltd.

di Mauro, F., Caristi, P., Couderc, S., Di Maria, A., Ho, L., Grewal, B. K., . . . Zaher, S. (2013). Islamic Finance in Europe. Frankfurt am Main.

El-Hawary, D., Grais, W., \& Iqbal, Z. (2007). Diversity in the regulation of Islamic Financial Institutions. The Quarterly Review of Economics and Finance, 46(5), 778-800. doi:10.1016/j.qref.2006.08.010

El Garah, W., Dsouli, O., Khan, N., \& Kakabadse, N. K. (2012). Spiritual capital: The co-evolution of an ethical framework based on Abrahamic religious values in the Islamic tradition. Journal of Management Development, 31(10), 1058-1076. doi:10.1108/02621711211281843

EY. (2014). World Islamic Banking Competitiveness Report 2013-14. Retrieved from

Fang, E. S. (2014). Islamic finance in global markets: Materialism, ideas and the construction of financial knowledge. Review of International Political Economy, 21(6), 1170-1202. doi:10.1080/09692290.2013.858229

Fang, E. S., \& Foucart, R. (2013). Western Financial Agents and Islamic Ethics. Journal of Business Ethics, 123(3), 475-491. doi:10.1007/s10551-013-1850-8

Ghannadian, F. F., \& Goswami, G. (2004). Developing economy banking: the case of Islamic banks. International Journal of Social Economics, 31(8), 740-752. doi:10.1108/03068290410546002

Gheeraert, L. (2014). Does Islamic finance spur banking sector development? Journal of Economic Behavior \& Organization, 103, 4-20. doi:10.1016/j.jebo.2014.02.013

Ginena, K. (2014). Sharī'ah risk and corporate governance of Islamic banks. Corporate Governance: The international journal of business in society, 14(1), 86-103. doi:10.1108/cg-03-2013-0038

Godlewski, C. J., Turk-Ariss, R., \& Weill, L. (2013). Sukuk vs. conventional bonds: A stock market perspective. Journal of Comparative Economics, 41(3), 745-761. doi:10.1016/j.jce.2013.02.006

Hamza, H. (2013). Sharia governance in Islamic banks: effectiveness and supervision model. International Journal of Islamic and Middle Eastern Finance and Management, 6(3), 226-237. doi:10.1108/imefm-02-20130021

Haniffa, R., \& Hudaib, M. (2007). Exploring the Ethical Identity of Islamic Banks via Communication in Annual Reports. Journal of Business Ethics, 76(1), 97-116. doi:10.1007/s10551-006-9272-5

Hassan, A., Chachi, A., \& Latiff, S. A. (2008). Islamic Marketing Ethics and its impact on customer satisfaction in the Islamic Banking industry. Journal of Islamic Economics, 21(1), 23-40.

Hossan Chowdhury, M. (2011). Ethical issues as competitive advantage for bank management. Humanomics, 27(2), 109-120. doi:10.1108/08288661111135117

Ibrahim, M. H., \& Mirakhor, A. (2014). Islamic finance: An overview. Pacific-Basin Finance Journal, $28,2-6$. doi:10.1016/j.pacfin.2014.02.002

Jawadi, F., Jawadi, N., \& Louhichi, W. (2014). Conventional and Islamic stock price performance: An empirical investigation. International Economics, 137, 73-87. doi:10.1016/j.inteco.2013.11.002

Johnes, J., Izzeldin, M., \& Pappas, V. (2014). A comparison of performance of Islamic and conventional banks 2004-2009. Journal of Economic Behavior \& Organization, 103, 93-107. doi:10.1016/j.jebo.2013.07.016

Khan, F. (2010). How 'Islamic' is Islamic Banking? Journal of Economic Behavior \& Organization, 76(3), 805820. doi:10.1016/j.jebo.2010.09.015

Khan, M., \& Bhatti, I. (2008a). Development in Islamic banking: a financial risk-allocation approach. The Journal of Risk Finance, 9(1), 40-51. doi:10.1108/15265940810842401

Khan, M., \& Bhatti, I. (2008b). Islamic banking and finance: on its way to globalization. Managerial Finance, 34(10), 708-725. doi:10.1108/03074350810891029

Lahrech, N., Lahrech, A., \& Boulaksil, Y. (2014). Transparency and performance in Islamic banking. International Journal of Islamic and Middle Eastern Finance and Management, 7(1), 61-88. doi:10.1108/imefm-062012-0047 
Malik, M., Malik, A., \& Mustafa, W. (2011). Controversies that make Islamic banking controversial: An analysis of issues and challenges. American Journal of Social and Management Sciences, 41-46. doi:10.5251/ajsms.2011.2.1.41.46

Mallin, C., Farag, H., \& Ow-Yong, K. (2014). Corporate social responsibility and financial performance in Islamic banks. Journal of Economic Behavior \& Organization, 103, 21-38. doi:10.1016/j.jebo.2014.03.001

Mansour, W., Ben Abdelhamid, M., Masood, O., \& Niazi, G. S. K. (2010). Islamic banking and customers' preferences: the case of the UK. Qualitative Research in Financial Markets, 2(3), 185-199. doi: $10.1108 / 17554171011091746$

Masood, O., Abdul Rehman, A., \& Masood, O. (2012). Why do customers patronize Islamic banks? A case study of Pakistan. Qualitative Research in Financial Markets, 4(2/3), 130-141. doi:10.1108/17554171211252475

Mohamad, S. (2014). Is Islamic Finance, Social Finance? Journal of Emerging Economies and Islamic Research, 2(2).

Mohamad, S., Othman, J., Roslin, R., \& Lehner, O. M. (2014). The use of Islamic hedging instruments as nonspeculative risk management tools. Venture Capital, 16(3), 207-226. doi:10.1080/13691066.2014.922824

Paldi, C. (2014). Capital Adequacy, Liquidity, and Risk: Is Islamic Banking Too Expensive? Journal of Finance and Bank Management, 2(2), 173-177.

Parboteeah, K. P., Hoegl, M., \& Cullen, J. B. (2007). Ethics and Religion: An Empirical Test of a Multidimensional Model. Journal of Business Ethics, 80(2), 387-398. doi:10.1007/s10551-007-9439-8

Paulet, E. (2011). Banking ethics. Corporate Governance: The international journal of business in society, 11(3), 293-300. doi:10.1108/14720701111138715

Paulet, E., Parnaudeau, M., \& Relano, F. (2014). Banking with Ethics: Strategic Moves and Structural Changes of the Banking Industry in the Aftermath of the Subprime Mortgage Crisis. Journal of Business Ethics. doi:10.1007/s10551-014-2274-9

Perry, F., \& Rehman, S. (2011). Globalization of Islamic Finance: Myth or Reality. International Journal of Humanities and Social Science, 1(19), 107-119.

Rethel, L. (2011). Whose legitimacy? Islamic finance and the global financial order. Review of International Political Economy, 18(1), 75-98. doi:10.1080/09692290902983999

Richardson, B. J. (2008). Keeping Ethical Investment Ethical: Regulatory Issues for Investing for Sustainability. Journal of Business Ethics, 87(4), 555-572. doi:10.1007/s10551-008-9958-y

San-Jose, L., Retolaza, J. L., \& Gutierrez-Goiria, J. (2011). Are Ethical Banks Different? A Comparative Analysis Using the Radical Affinity Index. Journal of Business Ethics, 100(1), 151-173. doi:10.1007/s10551-0110774-4

Shamsudin, M. Y., Salamon, H., \& Abu-Hussin, M. F. (2014). Form And Substance In Islamic Finance: Analysis of Deferred Payment Sales International Journal of Islamic and Civilizational Studies, 1(1), 11-21.

Siddiqui, A. (2008). Financial contracts, risk and performance of Islamic banking. Managerial Finance, 34(10), 680-694. doi:10.1108/03074350810891001

Souaiaia, A. E. (2014). Theories and Practices of Islamic Finance and Exchange Laws: Poverty of Interest. International Journal of Business and Social Science, 5(12), 34-52.

Uppal, J., \& Mangla, I. (2014). Islamic Banking and Finance Revisited after Forty Years: Some Global Challenges. Journal of Finance Issues, 13(1), 16-27.

Valeva, M. (2012). Theoretische Grundlagen ethischer Bankbetriebslehre. Wiesbaden: Springer-Gabler.

Wajdi Dusuki, A. (2008). Understanding the objectives of Islamic banking: a survey of stakeholders' perspectives. International Journal of Islamic and Middle Eastern Finance and Management, 1(2), 132-148. doi:10.1108/17538390810880982

Wajdi Dusuki, A., \& Irwani Abdullah, N. (2007). Why do Malaysian customers patronise Islamic banks? International Journal of Bank Marketing, 25(3), 142-160. doi:10.1108/02652320710739850 